\title{
Atrial Natriuretic Peptide Transcription, Secretion, and Glomerular Receptor Activity during Mineralocorticoid Escape in the Rat
}

\author{
Barbara J. Ballermann, Kenneth D. Bloch, J. G. Seidman, and Barry M. Brenner \\ Laboratory of Kidney and Electrolyte Physiology and Department of Medicine, Brigham and Women's Hospital and Harvard \\ Medical School, and Department of Genetics, Harvard Medical School, Boston, Massachusetts 02115
}

\begin{abstract}
The mechanisms that mediate renal "escape" from the sodiumretaining effects of mineralocorticoids are incompletely understood. This study was undertaken to determine whether atrial natriuretic peptide (ANP) may play a role in the escape phenomenon. Immunoreactive $A N P$ in rat plasma increased 2.5-fold above baseline values at 12 and $24 \mathrm{~h}$ after a single depot injection of desoxycorticosterone acetate in oil and returned to baseline thereafter. In addition, specific pre-pro-ANP messenger RNA content in rat atria was significantly elevated as early as $12 \mathrm{~h}$ after mineralocorticoid administration and remained elevated at 24, 48, and $72 \mathrm{~h}$, indicating a prompt and sustained increase in ANP biosynthesis. Renal glomerular ANP receptor density was down-regulated appropriately with rising plasma ANP levels, and receptor affinity was unchanged. Thus, mineralocorticoid administration in the rat is a powerful stimulus for ANP release and for atrial myocyte ANP synthesis, which suggests a potential role for this hormone in overriding mineralocorticoid-induced renal sodium retention.
\end{abstract}

\section{Introduction}

Primary hyperaldosteronism and excess exogenous mineralocorticoid result in transient renal sodium retention followed within a few days by a return to neutral sodium balance. Escape from mineralocorticoid-induced renal sodium retention appears to be mediated largely by extracellular fluid volume expansion (1), although the exact mechanisms,are incompletely understood. During mineralocorticoid escape, the specific effects of mineralocorticoids on sodium transport are not inhibited, which suggests that the increase in renal sodium excretion during escape is mediated by other mechanisms. Evidence favoring hemodynamic factors in escape has been reported. In dogs given mineralocorticoids, escape is not observed if the renal perfusion pressure is kept constant as mean systemic arterial pressure rises (2), and in rats escape is associated with elevated renal peritubular capillary and interstitial hydraulic pressures (3). It has also been

Address correspondence and reprint requests to Dr. Ballermann, Laboratory of Kidney and Electrolyte Physiology, Brigham and Women's Hospital, 75 Francis St., Boston, MA 02115. 1986.

Received for publication 18 March 1986 and in revised form 24 April

J. Clin. Invest.

(c) The American Society for Clinical Investigation, Inc.

0021-9738/86/09/0840/04 $\$ 1.00$

Volume 78, September 1986, 840-843 postulated that a natriuretic factor may mediate mineralocorticoid escape (1).

Atrial natriuretic peptide $(\mathrm{ANP})^{1}$ is released from atria in response to acute (4) or chronic (5) volume expansion. Also, ANP markedly increases renal sodium excretion, in part by changes in renal hemodynamics (6). These findings favor a role for this hormone in mineralocorticoid escape. To determine whether ANP synthesis, secretion, and target tissue receptor density are altered during mineralocorticoid escape, we measured urinary electrolyte excretion, plasma immunoreactive ANP (iANP) concentrations, relative atrial pre-pro-ANP messenger RNA (mRNA) content, and renal glomerular ANP receptor density and affinity as a function of time after a single depot injection of desoxycorticosterone acetate (DOCA).

\section{Methods}

50 male Sprague-Dawley rats weighing $225-250 \mathrm{~g}$ were kept in individual metabolic cages for 7-9 d. Twice daily, rats were fed $12 \mathrm{~g}$ of a sodiumfree diet (Teklad, Madison, WI) that was supplemented with $2.2 \mathrm{~g} / \mathrm{kg}$ sodium chloride, thus providing $0.5-1.0$ meq sodium per day. Free access to deionized water was allowed. Urine was collected at 24-h intervals to determine sodium and potassium excretion. On the 6th day, 30 rats were given $10 \mathrm{mg}$ DOCA in sesame oil subcutaneously at 9 a.m., and were killed by decapitation at 24,48 , and $72 \mathrm{~h}$ after the initiation of DOCA treatment ( $n=10$ per time point). 10 rats were given DOCA at 9 p.m. on the 6th day, and were killed at 9 a.m. the next morning, thus providing the 12-h time point. 10 rats received sesame oil without DOCA and served as controls. Controls were killed either on the day they received sesame oil $(n=4)$ or 24 or $48 \mathrm{~h}$ later $(n=3$ each). Administration of sesame oil without DOCA did not alter urinary sodium or potassium excretion, plasma iANP, glomerular ANP receptor binding parameters, or atrial pre-pro-ANP mRNA content; thus, values for controls were combined. In addition, 12 rats were allowed ad lib. access to regular rat chow (Ralston Purina Co., St. Louis, MO) and tap water and were not housed in metabolic cages. Of these, six were given DOCA and six received vehicle injections. These rats were killed $24 \mathrm{~h}$ later for the determination of plasma iANP only. To exclude any possible effects of diurnal variation, all animals were killed between 9 and 10 a.m.

To determine plasma iANP concentrations, trunk blood was collected within the first $15 \mathrm{~s}$ of decapitation from each rat in chilled test tubes containing EDTA (10 mg), aprotinin (1,500 kallikrein inhibitor units), and soybean trypsin inhibitor (10 N-benzoyl-L-arginine-ethyl ester inhibitor units). Plasma was immediately separated from blood and extracted on a $\mathrm{C}_{18}$ cartridge (Sep Pak; Waters Assoc., Milford MA) as described by Lang et al. (4). Recovery of ANP from the cartridge was $72 \pm 5 \%$ as determined in four separate experiments by addition of ${ }^{125} \mathrm{I}$ -

1. Abbreviations used in this paper: ANP, atrial natriuretic peptide; DOCA, desoxycorticosterone acetate; iANP, immunoreactive ANP. 
labeled ANP to plasma, and in two experiments by addition of unlabeled ANP to plasma. Recovery values from these experiments were used to correct ANP levels for all samples. ANP radioimmunoassay was performed with a commercially available radioimmunoassay kit (Peninsula Laboratories, Belmont, CA), using rabbit antiserum raised against the 28 amino acid human alpha ANP, which was $100 \%$ cross-reactive with rat alpha ANP. Plasma iANP concentrations determined from two different dilutions of the plasma extract gave essentially identical values $(n=10)$. For samples in which plasma iANP was determined at two different dilutions, the mean of the two values is reported.

To determine glomerular ANP receptor density and affinity, glomeruli were isolated from the kidneys of each rat as previously described (7). Isolated glomeruli were incubated with constant concentrations of ${ }^{125} \mathrm{I}-$ alpha human ANP and varying concentrations (30-3,000 pM) of unlabeled ANP (Peninsula Laboratories) in an ice-water bath for $3 \mathrm{~h}$. The assay buffer consisted of, in $\mathrm{mM}: \mathrm{NaCl}, 137, \mathrm{KCl}, 5.4, \mathrm{KH}_{2} \mathrm{PO}_{4}, 0.44$, $\mathrm{Na}_{2} \mathrm{HPO}_{4}, 0.33, \mathrm{MgSO}_{4}, 0.40, \mathrm{MgCl}_{2}, 0.50, \mathrm{CaCl}_{2}, 1.25$, and $\mathrm{NaHCO}_{3}$, 4.0, to which were added bovine serum albumin (BSA), $0.20 \mathrm{~g} / \mathrm{dl}$, Hepes, $20 \mathrm{mM}$, bacitracin, $1 \mathrm{mM}$, and phenylmethylsulfonyl fluoride, $1 \mathrm{mM}$, pH 7.4. The glomerular ANP receptor assay was previously extensively validated (8); binding equilibrium was achieved reliably at $3 \mathrm{~h}$ of incubation, degradation of ANP by glomeruli was negligible under the conditions described, and binding experiments using increasing concentrations of radiolabeled ANP gave very similar results to those obtained with competitive binding inhibition studies. Glomerular ANP receptor density and equilibrium dissociation constants $\left(K_{d}\right)$ were determined from the binding data using the LIGAND program (9). The receptor concentration is expressed in femtomoles per milligram glomerular protein, the latter determined by the method of Lowry et al. (10).

Atrial pre-pro-ANP mRNA content was measured by dot hybridization analysis (11). Total RNA was isolated from both cardiac atria of each rat as described by Chirgwin et al. (12). For each sample, four dilutions of RNA were hybridized with a ${ }^{32}$ P-labeled Nick-translated probe prepared from the ANP complementary DNA (cDNA) (13), and with a Nick-translated probe derived from an A50 cDNA clone. The A50 cDNA clone contains sequences for a "housekeeping" mRNA of unknown identity, which is constitutively expressed at high levels in myocardial tissue (14). Under the assumption that atrial A50 mRNA content remains stable, hybridization with this clone was used as an index of total RNA for each sample. After hybridization, the nitrocellulose filters containing the RNA were washed at high stringency to minimize cross-reactivity of the probes with other RNA species. For each sample, the quantity of ANP probe hybridization at the four dilutions was plotted as a function of $\mathrm{A} 50$ probe hybridization. The slope of the linear regression of this plot, which also represents the mean ratio of pre-pro-ANP mRNA/ A50 mRNA at the four dilutions, was taken as a quantitative index of relative pre-pro-ANP mRNA content.

Data are presented as the mean \pm standard error of the mean. Statistical testing was by analysis of variance and comparisons to the control group were made by Dunnett's method for multiple comparisons (15).

\section{Results}

The results of this study are shown in Fig. 1. During the first 24 $\mathrm{h}$ after DOCA administration, sodium excretion was significantly reduced from $0.60 \pm 0.03$ to $0.32 \pm 0.03 \mathrm{meq} / 24 \mathrm{~h}(P<0.01)$, and potassium excretion rose from $4.3 \pm 0.1$ to $5.1 \pm 0.1 \mathrm{meq} / 24$ $\mathrm{h}(P<0.01)$. Sodium excretion rates returned to control values during the second 24-h period, indicating escape from the sodium-retaining effects of DOCA. Plasma iANP increased from $262 \pm 40 \mathrm{pg} / \mathrm{ml}$ in controls to $638 \pm 71 \mathrm{pg} / \mathrm{ml}$ at $12 \mathrm{~h}$, and remained elevated at $539 \pm 59 \mathrm{pg} / \mathrm{ml} 24 \mathrm{~h}$ after the initiation of DOCA treatment (for both, $P<0.01$ ). At 48 and $72 \mathrm{~h}$, plasma iANP levels were not different from baseline values. The baseline plasma iANP concentration in rats given regular rat chow ad lib. and not housed in metabolic cages was $73 \pm 10 \mathrm{pg} / \mathrm{ml}(n=6)$.
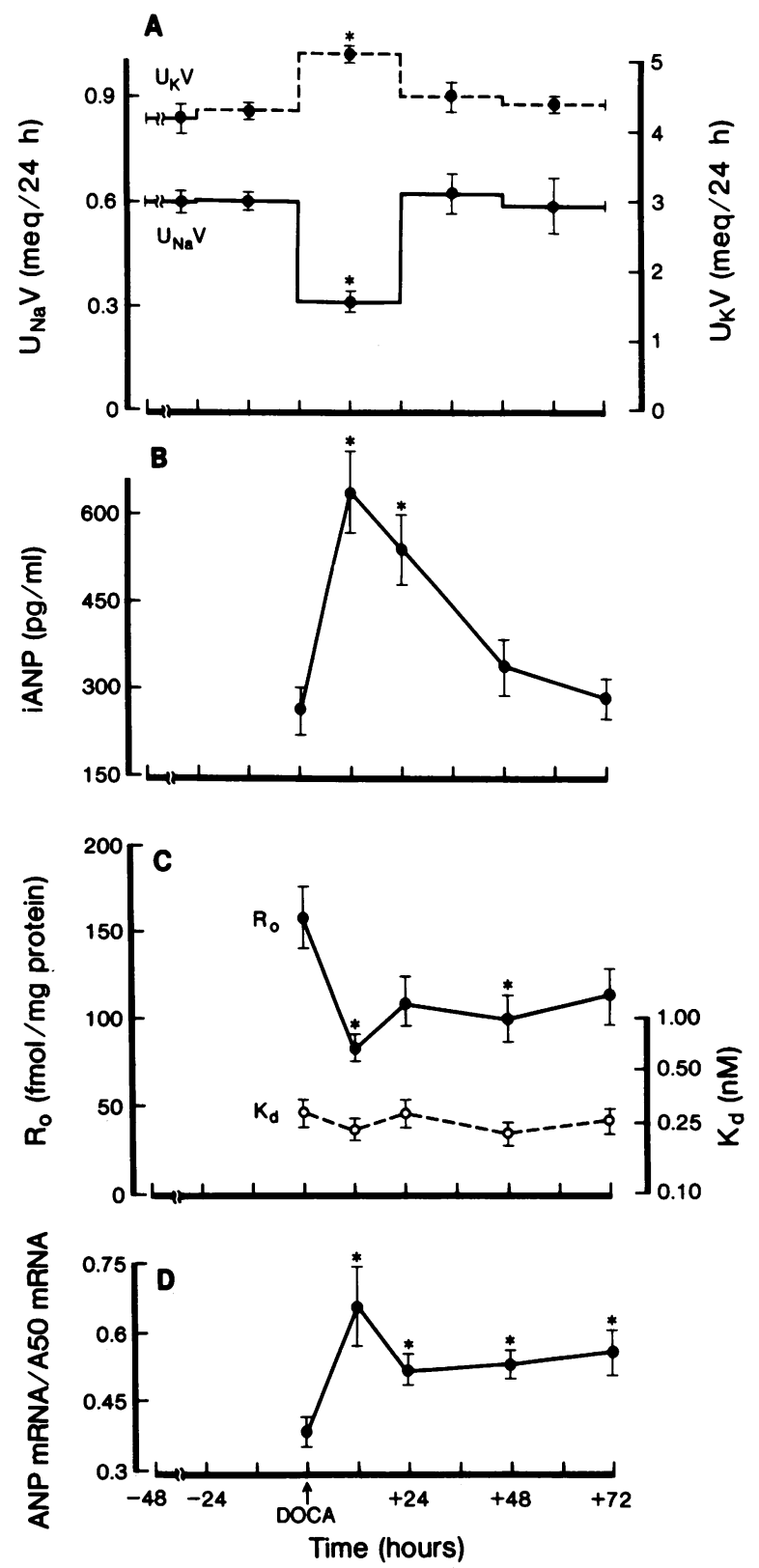

Figure 1. The profile of $(A)$ 24-h urinary sodium $\left(\mathrm{U}_{\mathrm{Na}} \mathrm{V}\right)$ and potassium excretion $\left(\mathrm{U}_{\mathrm{K}} \mathrm{V}\right),(B)$ plasma iANP, $(C)$ renal glomerular ANP receptor density $\left(\mathrm{R}_{0}\right)$ and equilibrium $K_{d}$, and $(D)$ relative atrial prepro-ANP mRNA (the ratio of pre-pro-ANP mRNA/A50 mRNA), as a function of time after a single depot injection of DOCA, $10 \mathrm{mg}$. All data points reflect mean values for 10 measurements at each time point, except in $D$, where the 12-h time point represents the mean of eight measurements $\left({ }^{*} P<0.05\right)$.

Although baseline levels were much lower in rats given the regular diet and not housed in metabolic cages, plasma iANP still increased threefold $24 \mathrm{~h}$ after DOCA administration to $225 \pm 43$ $\mathrm{pg} / \mathrm{ml}(P<0.001)$. Differences in baseline iANP levels between the test diet and the standard lab chow (Ralston Purina Co.) were due, at least in part, to differences in dietary composition, as rats given the salt-supplemented Teklad diet ad lib. and not housed in metabolic cages were found to have baseline iANP levels of $166 \pm 22 \mathrm{pg} / \mathrm{ml}(n=9) .12 \mathrm{~h}$ after DOCA administration, glomerular ANP receptor density averaged $83 \pm 7 \mathrm{fmol} / \mathrm{mg}$ glomerular protein compared with $158 \pm 18 \mathrm{fmol} / \mathrm{mg}$ in controls $(P$ 
$<0.05)$. The glomerular ANP receptor density at $24 \mathrm{~h}$ averaged $111 \pm 14 \mathrm{fmol} / \mathrm{mg}$ and remained relatively constant thereafter. No change in the glomerular ANP receptor affinity was observed.

The ratio of atrial pre-pro-ANP mRNA/A50 mRNA rose from $0.39 \pm 0.02$ to $0.66 \pm 0.0812 \mathrm{~h}$ after DOCA treatment $(P$ $<0.05$ ), and remained elevated thereafter at levels of $0.51 \pm 0.04$, $0.53 \pm 0.03$, and $0.56 \pm 0.05$ at 24,48 , and $72 \mathrm{~h}$, respectively (for all, $P<0.05$ ).

\section{Discussion}

The findings in this study indicate that DOCA administration in the rat is a powerful stimulus for ANP release. It is likely that ANP release was provoked, at least in part, by extracellular fluid volume expansion, that was brought about by DOCA-induced renal salt retention. Acute plasma volume expansion in the rat was previously reported to result in an increase in plasma iANP of similar magnitude but of much briefer duration than that observed in this study (5), a finding that was interpreted to indicate that the rise in plasma ANP participates in the excretion of an acute volume load. It is also possible that DOCA may have stimulated ANP release directly. Garcia et al. (16) reported marked increases in atrial and plasma ANP levels in response to combination therapy with glucocorticoids and mineralocorticoids in adrenalectomized rats, a response that was not seen with either agent alone. Interestingly, when rats were given saline to drink, a further increase in both atrial and plasma ANP levels was observed, which supports the theory of an independent effect of volume expansion on ANP synthesis and secretion (16).

It is evident from Fig. 1 that the increase in plasma iANP and the return to neutral sodium balance appear to coincide, although it is not ruled out that the rise in iANP may precede the escape from mineralocorticoid-induced sodium retention. Since ANP is a potent natriuretic agent, it is logical to postulate from these findings that the marked rise in circulating iANP concentration may play a role in initiating the escape phenomenon. It was not possible to pinpoint the moment of escape more precisely with this protocol, since there was marked diurnal variation in sodium excretion even when rats were fed at exactly 12-h intervals. The fall of plasma iANP to near normal values at 48 and $72 \mathrm{~h}$ indicates that the maintenance of neutral sodium balance in this model does not require elevated ANP levels. Whether this is also the case at higher salt intakes or with daily DOCA administration remains to be evaluated.

Plasma iANP in the present study was determined using extracts of plasma in order to avoid overestimation of iANP due to nonspecific interfering substances in plasma. Despite this, the baseline values in rats given the test diet twice daily and kept in metabolic cages are higher than those reported by some investigators $(4,17)$, although even higher values have also been observed (5). The high baseline levels in the present study appear not to be due to the method of blood collection, or to interfering substances in the plasma extract, as baseline levels in rats not housed in metabolic cages, on standard chow with ad lib. access to food and water, are very similar to the lower levels reported by Horky et al. in conscious, unrestrained rats (17). A threefold increase in plasma iANP was still observed in these rats $24 \mathrm{~h}$ after DOCA administration, even with lower baseline levels. The difference in baseline values appears to be due, in part, to differences in dietary composition, as rats given the test diet ad lib. in regular cages were found to have baseline iANP levels that were more than twice as high as those given regular rat chow.
Whether the stress on them of being housed in metabolic cages, and the twice daily feeding routine, caused further elevations in baseline plasma iANP levels remains to be clarified. Since rats maintain neutral sodium balance despite very different baseline iANP levels, it is postulated that other sodium-retaining systems must counterbalance the natriuretic effects of ANP, or that renal responsiveness to ANP changes.

The pattern of urinary electrolyte excretion is consistent with the time course of mineralocorticoid escape in the rat. In meticulous balance studies Möhring and Möhring (18) showed that escape occurred within $48 \mathrm{~h}$ after the administration of DOCA in rats given $\sim 2.5$ meq of sodium per day. Pilot studies in our own laboratory using daily DOCA injection had shown that sodium retention during the first $24 \mathrm{~h}$ after mineralocorticoid administration could be most reliably demonstrated with a sodium intake of $0.5-1.0 \mathrm{meq} / \mathrm{d}$, and escape occurred by $48 \mathrm{~h}$. The sodium intake in this study corresponds to $\sim 3 \mathrm{meq} / \mathrm{kg}$ per $\mathrm{d}$, which would be $210 \mathrm{meq} / \mathrm{d}$ for the average $70 \mathrm{~kg}$ human. A decrease in potassium excretion in the second 24-h period after initiation of mineralocorticoid treatment in the rat was previously described (18). The return to baseline values of potassium excretion in this study most likely reflects the moderate sodium intake. Potassium wasting with continued mineralocorticoid activity is enhanced only if distal tubule sodium delivery is large, which would occur with a high sodium intake.

Renal glomerular ANP receptor density was determined in this study to test the hypothesis that mineralocorticoid escape may be mediated by enhanced tissue responsiveness to ANP due to increased ANP receptor expression. The finding that the density of glomerular ANP receptors was down-regulated appropriately (8) as plasma iANP levels increased would tend to rule out this possibility. Also, enhanced ANP receptor affinity was ruled out as a possible mechanism for greater renal responsiveness to ANP. These findings of course do not preclude enhanced renal responsiveness to ANP on the basis of changes in postreceptor events. Since hormone receptor upregulation generally requires new protein synthesis, it is not surprising that glomerular ANP receptor density did not return to control values as plasma iANP levels decreased at 48 and $72 \mathrm{~h}$ after DOCA administration.

Pre-pro-ANP mRNA represents 1-3\% of total atrial mRNA, reflecting very active transcription of the ANP gene $(13,19)$. The increase in atrial pre-pro-ANP mRNA content, averaging $70 \%$ above baseline at $12 \mathrm{~h}$, therefore represents a substantial rise in atrial myocyte pre-pro-ANP content, and indicates that ANP synthesis was significantly augmented. Whether the increase in atrial pre-pro-ANP mRNA content results from direct stimulation of ANP gene transcription by DOCA, from feedback stimulation of ANP gene transcription in response to enhanced atrial myocyte ANP release, or from reduced degradation of prepro-ANP mRNA, remains to be determined. Mineralocorticoids are known to signal new protein synthesis in some target tissues by interacting with nuclear receptors; direct stimulation of ANP gene transcription could thus be mediated by a similar mechanism. Further studies will be required to determine to what extent newly synthesized ANP is added to the storage pool or is secreted directly during mineralocorticoid escape.

In conclusion, a single depot injection of DOCA given to rats results in transient sodium retention, and is followed by return to neutral sodium balance within $48 \mathrm{~h}$. The marked rise in plasma iANP concentration that coincided with the return to normal sodium balance raises the possibility that this powerful 
natriuretic hormone may play a role in initiating the phenomenon of DOCA escape. The increase in atrial pre-pro-ANP mRNA content within $12 \mathrm{~h}$ of DOCA administration indicates substantially augmented atrial ANP synthesis, which may have contributed to the increased secretion of ANP.

\section{Acknowledgments}

The A50 cDNA probe was kindly provided by $\mathrm{B}$. Nadel-Ginard. Jerome B. Zisfein and Stacy Smith provided expertise in dissecting the cardiac atria.

This study was supported by National Institutes of Health grants 35930 and AI-18437, and by grants from Wyeth Laboratories and the Mallinkrodt Foundation. Kenneth D. Bloch was supported by the Leukemia Society of America Inc.

\section{References}

1. Knox, F. G., J. C. Burnett, Jr., D. E. Kohan, W. S. Spielman, and J. C. Strand. 1980. Escape from the sodium retaining effects of mineralocorticoids. Kidney Int. 17:263-276.

2. Hall, J. E., J. P. Granger, M. J. Smith, Jr., and A. J. Premen. 1984. Role of renal hemodynamics and arterial pressure in aldosterone "escape." Hypertension. 6(Suppl. I):I183-I192.

3. Burnett, J. C., J. A. Haas, and M. S. Larson. 1985. Renal interstitial pressure in mineralocorticoid escape. Am. J. Physiol. 249:F396-F399.

4. Lang, R. E., H. Tholken, D. Ganten, F. C. Luft, H. Ruskoaho, and T. Unger. 1985. Atrial natriuretic factor-a circulating hormone stimulated by volume loading. Nature (Lond.). 314:264-266.

5. Tanaka, I., K. S. Misono, and T. Inagami. 1984. Atrial natriuretic factor in rat hypothalamus, atria and plasma: determination by specific radioimmunoassay. Biochem. Biophys. Res. Commun. 124:663-668.

6. Ballermann, B. J., and B. M. Brenner. 1985. Biologically active atrial peptides. J. Clin. Invest. 76:2041-2048.

7. Ballermann, B. J., K. L. Skorecki, and B. M. Brenner. 1984. Reduced glomerular angiotensin II receptor density in early, untreated diabetes mellitus in the rat. Am. J. Physiol. 247:F110-F116.
8. Ballermann, B. J., R. L. Hoover, M. J. Karnovsky, and B. M. Brenner. 1985. Physiologic regulation of atrial natriuretic peptide receptors in rat renal glomeruli. J. Clin. Invest. 76:2049-2056.

9. Munson, P. J., and D. Rodbard. 1980. LIGAND: a versatile computerized approach for characterization of ligand binding systems. Anal. Biochem. 107:220-239.

10. Lowry, O. H., N. J. Rosebrough, A. L. Farr, and R. J. Randall. 1951. Protein measurement with the Folin phenol reagent. J. Biol. Chem. 193:265-275.

11. Gick, G. C., and C. Bancroft. 1985. Regulation by calcium of prolactin and growth hormone mRNA sequences in primary cultures of rat pituitary cells. J. Biol. Chem. 260:7614-7618.

12. Chirgwin, J. M., A. E. Przybyla, R. W. MacDonald, and W. J. Rutter. 1979. Isolation of biologically active ribonucleic acid from sources enriched in ribonuclease. Biochemistry. 18:5294-5299.

13. Seidman, C. E., A. D. Duby, E. Choi, R. M. Graham, E. Haber, C. Homcy, J. A. Smith, and J. G. Seidman. 1984. The structure of rat preproatrial natriuretic factor as defined by a complementary DNA Clone. Science (Wash. DC). 225:324-326.

14. Nguyen, H. T., R. M. Medford, and B. Nadel-Ginard. 1983. Reversibility of muscle differentiation in the absence of commitment: analysis of a myogenic cell line temperature-sensitive for commitment. Cell. 34:281-293.

15. Dunnett, C. W. 1964. New tables for multiple comparisons with a control. Biometrics. 20:482-491.

16. Garcia, R., W. Debinske, J. Gutkowska, O. Kuchel, G. Thibault, J. Genest, and M. Cantin. 1985. Gluco- and mineralocorticoids may regulate the natriuretic effect and the synthesis and release of atrial natriuretic factor by the rat atria in vivo. Biochem. Biophys. Res. Commun. 131:806-814.

17. Horky, K., J. Gutkowska, R. Garcia, G. Thibault, J. Genest, and M. Cantin. 1985. Effect of different anesthetics on immunoreactive atrial natriuretic factor concentrations in rat plasma. Biochem. Biophys. Res. Commun. 129:651-657.

18. Möhring, J., and B. Möhring. 1972. Reevaluation of DOCA escape phenomenon. Am. J. Physiol. 223:1237-1245.

19. Seidman, C. E., K. D. Bloch, K. A. Klein, J. A. Smith, and J. G. Seidman. 1984. Nucleotide sequences of human and mouse atrial natriuretic factor genes. Science (Wash. DC). 226:1206-1209. 